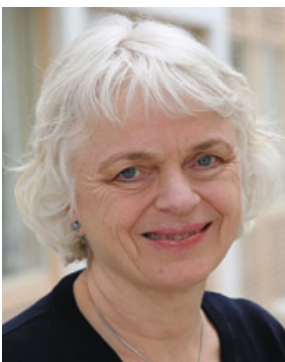

\title{
Liten og åleine på sjukehus
}

\section{Foreldre til sjuke barn blei ute- stengde frå norske sjukehus til langt ut i 1960-åra. Det er inga ærerik historie.}

Sommaren 1959 blei eg lagt inn på sjukehus i Stavanger med stivt kne og mistanke om tuberkulose. Eg var knapt to år gammal, hadde lært meg alle navna på kyrne i fjøset og var flink til å herma etter hesten. Fleire gonger i veka reiste mor til Stavanger for å besøka meg, tre timar med båt kvar veg, men ho kom aldri lenger enn til døra på barneavdelinga. Godt skjult bak eit skjermbrett fekk ho lov til å stå og sjå på meg. Det var best slik, fekk ho vita. Legen var redd for at ho kunne bera med seg smitte, dessutan blei det så mykje gråting, bråk og styr viss mødrene kom og gjekk.

Etter seks veker kom eg heim som eit alvorleg barn, mutt og inneslutta. Eg hugsa ikkje, eller ville ikkje hugsa, navnet på kyrne og viste inga interesse for å laga hestelydar. Likevel var eg heldig som kom heim så raskt, fri frå mistanken om tuberkulose. Dei som blei ramma av den frykta sjukdommen, fekk på alle vis ein mykje tyngre lagnad. Hundrevis av norske barn og ungdommar med tuberkulose låg åleine på sjukehus og sanatorier i månader og år.

Det er vanskeleg å ta inn over seg den einsemda desse unge sjelene måtte tola, og all maktesløysa foreldra må ha opplevd. Mor mi har aldri klart å forsona seg med at ho ga etter for den kvitkledde overmakta og stilte seg lydig bak skjermbrettet. Eg prøver å seia at ingen kunne forvente eit opprør frå henne som enkeltperson, men då ristar ho på hovudet og spør: «Visste dei verkeleg ikkje betre?» Det er eit spørsmål som peikar langt utover seg sjølv: Kvifor blei mor og far utestengde i tiår etter tiår, medan dei i dag er inkluderte som den mest naturlege ting i verda?

Hildegunn Sundal har, gjennom si doktoravhandling ved Universitetet i Bergen, gitt viktig innsikt i desse spørsmåla. Ho har analysert lærebøker, bilete og anna dokumentasjon heilt frå 1877 og fram til i dag. For å forstå må vi sjå på samfunnskonteksten, seier ho, inspirert av den franske filosofen Michel Foucault. Med industrialiseringa på slutten av 1800-talet og byrjinga av 1900-talet, kom institusjonaliseringa av barn. På same tid kom også ideane om det sårbare og umodne barnet, og styresmaktene innførte fleire lover for å verne barn. «Dette synet på barn ser ikke ut til å ha hatt gjennomslag i moderne sykepleie, for da ville det ha vært naturlig å inkludere foreldrene i sykehusene for å beskytte barnet», skriv Sundal.

I ei lærebok i sjukepleie frå 1941 blir det anbefalt at mor og far skal få besøka barn på sjukehus, likevel står den gamle praksisen ved lag i fleire tiår. Redselen for smitte kan ha bidratt til dette, og sjukehusa kan ha sett seg tent med at foreldra ikkje blanda seg inn i behandlinga, seier Sundal. Når foreldra endeleg får sleppa til i 60-åra, er antibiotika blitt vanleg, og det har skjedd ei storstilt utbygging av helsevesenet. Det er mangel på sjukepleiarar, og mor og far blir med eitt ein nødvendig ressurs.

50 år etter at eg kom på sjukehus med stivt kne, blei Ingrid, dottera mi, operert for skoliose ved St. Olavs hospital. Vi foreldra var saman med henne heile tida. Vi forlét ikkje operasjonssalen før ho hadde sovna, og då ho vakna igjen etter fem lange timar, stod ein sliten, men nøgd kirurg saman med oss og fortalde henne at alt hadde gått bra. Tanken på at vi skulle ha stått bak eit skjermbrett er heilt absurd.

Det er lett å ta dagens praksis for gitt og tenkja at «det skulle berre mangla», men historia viser til fulle at så enkelt er det ikkje. Det er slett ingen automatikk i at ny kunnskap blir gjort om til handling og ny praksis, det er diverre ei sanning innafor alle sektorar og fagfelt. For Norges forskingsråd er det difor eit heilt sentralt mål at forsking og kunnskap må takast i bruk. Dersom kunnskap blir liggjande brakk, kan dei negative konsekvensane bli svært store, både for eit næringsliv og ein offentleg sektor som treng verdiskaping og omstilling, og for enkeltmennesket som treng omsorg og gode tenester. For enkeltmenneske kan det til og med gjera svært vondt. Berre spør mor mi.

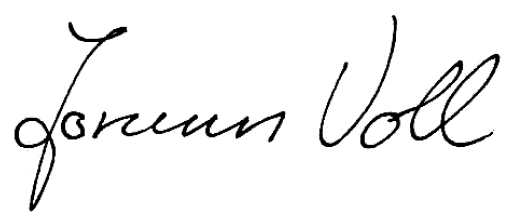

